\title{
ПРОБЛЕМНІ ПИТАННЯ ЗАКОНОДАВЧОГО УНОРМУВАННЯ ВІДШКОДУВАННЯ ФІЗИЧНОї ШКОДИ
}

\author{
НАУМОВА Анна Олександрівна - кандидат юридичних наук, доцент \\ кафедри кримінального права та кримінології факультету №6 Харківського \\ національного університету внутрішніх справ
}

DOI:10.32782/EP.2020.1.18

УДК 343.211

В статье проанализированы спорнъе вопросы определения понятия физического вреда в теории уголовного, уголовного процессуального права, медицинских критериев здоровья, бизического вреда, приииненного лииу. Изложенъ признаки, что раскрвивают сущность понятия Физического вреда, причиненного преступлением. Обоснована челесообразность законодательного закрепления в положениях УПК процессуальной прочедуръ возмещения физического вреда потерпевшему.

Ключевъе слова: фбизический вред, потерпевший, здоровъе, медицинские критерии, процедура.

Постановка проблеми

Найвищою соціальною цінністю в Україні на конституційному рівні визнається життя й здоров'я людини. Принцип пріоритету загальнолюдських цінностей свідчить про реальність визначеного в рамках державної політики права потерпілого від злочину на відшкодування матеріальної та моральної шкоди заподіяної злочином. Наслідками злочинного посягання на життя й здоров'я особи є спричинення фізичної шкоди потерпілому. Водночас у юридичній літературі не достатньо досліджено проблеми всебічного захисту життя й здоров'я потерпілого в кримінальному процесі, відшкодування йому в повному обсязі фізичної шкоди. У зв'язку 3 цим актуальним для кримінальної, кримінально процесуальної науки, слідчої, судової, експертної практики є дослідження ознак фізичної шкоди, ії критеріїв та надання визначення фізичної шкоди, вдосконалення кримінального процесуального законодавства.

Аналіз останніх досліджень i публікацій

Окремі аспекти, присвячені визначенню фізичної шкоди в кримінальному праві були предметом наукових розробок і дискусій та розглядалися Є. П. Гавриловим, О. В. Грищук, 3. 3. Зинатуліним, О. М. Ерделєвським. Водночас, в умовах реформування кримінального процесуального законодавства проблема відшкодування фізичної шкоди $\epsilon$ актуальною для науки кримінального, цивільного, кримінального процесуального права та потребує подальшого дослідження.

Формування мети та завдань

Метою статті $\epsilon$ визначення поняття «фізична шкода», розробка пропозицій до чинного законодавства, що стосуються відшкодування фізичної шкоди, спричиненої особі злочином. Завдання дослідження полягає в тому, щоб проаналізувати юридичну, медичну літературу, вивчити слідчу, судову, експертну практику, чинне кримінальне, кримінально процесуальне законодавство, визначити медичні ознаки здоров'я та фізичної шкоди, спричиненої особі злочином, процедуру ії відшкодування. 


\section{Виклад основного матеріалу}

Проблема визначення фізичної шкоди, завданої потерпілому, та процедура ії відшкодування не стала предметом глибокого комплексного наукового дослідження. Кримінально - процесуальний інститут відповідальності держави за свою діяльність перед людиною, у тому числі й за фізичну шкоду, спричинену злочином, потребує подальшого розвитку та удосконалення. Поняття «фізична шкода» як наукову категорію доцільно досліджувати дослідниками науки кримінального права та кримінального процесу 3 урахуванням медичних ознак та критеріїв.

Слід зазначити, що в юридичній літературі викладено різні підходи дослідників кримінального права до поняття фізичної шкоди . Слушною є думка С. І. Остапенко, що шкода - об'єктивна категорія, що заснована на праві й моралі та становить ті зміни, які настали в майновому, фізичному, психічному, моральному стані особи внаслідок вчинення злочину [1, с. 15].

О. В. Грищук вважає, що фізична шкода є матеріальною з природно наукової точки зору і разом із тим немайновою - це будь-які негативні зміни в організмі людини, котрі перешкоджають нормальному, 3 біологічної, фізіологічної, психічної точок зору, проходженню всіх психофізичних процесів людини. Негативні зміни настають в організмі потерпілого, тобто в матеріальній сфері, під впливом певних зовнішніх факторів. Зміни, у свою чергу, можуть потім призвести до негативних явищ у психічному стані, а також у майні особи [2]. 3. 3. Зінатуллін визначає фізичну шкоду як шкоду, заподіяну здоров'ю особи, яка в деяких випадках тягне за собою збитки у вигляді грошових витрат на відновлення здоров'я, поховання тощо [3, с. 7]. Аналіз праці О. М. Ерделєвського дозволив визначити, що він розглядає фізичну шкоду як шкоду матеріальну й немайнову. Шкідливі зміни відбуваються в тілесній (тобто матеріальній сфері потерпілого) під впливом певних зовнішніх впливів. Негативні зміни в психічній сфері можуть виражатися в обох видах страждань (моральна шкода), а негативні зміни в майновій сфері - у витратах, пов'язаних із корекцією або функціональною компенсацією тілесних недоліків, і втрати доходу [4]. Слушною є думка Е. П. Гаврилова, який розмежував моральну і фізичну шкоду, при цьому обидва види шкоди заподіюються безпосередньо особистості й викликають страждання - природну форму наслідків заподіяння шкоди особистості потерпілого. Їх основна відмінність полягає в тому, що моральна і фізична шкода відбивається в різних сферах людської життєдіяльності: відповідно ідеальної (духовної) і матеріальної (тілесної), що передбачає і відмінність використовуваних принципів оцінки заподіяної шкоди та ії компенсації [5, с. 28]. Зазначене свідчить про те, що в юридичній літературі відсутній єдиний підхід до визначення поняття фізичної шкоди. У зв'язку 3 цим вважаємо, що для визначення поняття фізичної шкоди в кримінально-процесуальному праві необхідно проаналізувати поняття здоров’я.

Вважаємо, що для дослідження поняття «фізична шкода» необхідно проаналізувати поняття «здоров'я». Дослідники медичних наук зазначають, що поняття здоров'я характеризується складністю, багатозначністю і неоднорідністю складу [6, с. 3]. Здоров’я - це стан повного фізичного, душевного й соціального благополуччя, а не тільки відсутність хвороб або фізичних дефектів» [7, с. 308]. У зазначеній дефініції викладені три самостійні категорії здоров'я: біологічний (фізіологічний), психологічний і соціальний. У науковій літературі дослідники відзначають, що взагалі здоров'я на біологічному рівні можна охарактеризувати як стан, протилежний хворобі. При цьому здоров'я не має чітких меж, тому що включає різні перехідні стани. Насамперед здоров'я - це природний стан організму, який характеризується повною врівноваженістю із зовнішнім середовищем (біосферою) і відсутністю будь-яких виражених хворобливих змін [8, с. 356]. Стан здоров'я може встановлюватися на основі суб'єктивних відчуттів конкретної людини в сукупності 3 даними клінічного обстеження, з урахуванням статі, віку, соціальних, кліматичних, географічних та метеорологічних умов проживання людини [9, с. 265].

Водночас, поняття здоров'я в медичній і юридичній літературі окремі дослідники 


\section{Кримінальне право, кримінальний процес та криміналістика}

визначають як певний об'єктивний фізіологічний стан людини, який вона мала до вчинення злочину [5; 10], а шкоду здоров'ю - як порушення анатомічної цілісності, фізіологічної функції органів або тканин, що виявляється в тілесному ушкодженні або захворюванні чи патологічному стані [11; 12].

Аналіз медичної, юридичної літератури, законодавства та слідчої, судової, експертної практики дозволяе зробити висновок, що в широкому значенні фізична шкода це шкода, завдана здоров'ю особі внаслідок вчинення відносно неї злочину.

Системний аналіз медичної, юридичної літератури дозволяє зробити висновок про те, що для правильного розуміння сутності та наслідків фізичної шкоди, доцільно дослідити її в медико-біологічному та юридичному аспектах.

У судовій медицині ушкодження - це порушення анатомічної цілісності, фізіологічної функції органів або тканин, що виникло в результаті впливу факторів навколишнього середовища [13, с. 34]. Водночас, тілесні ушкодження виражені в анатомічному порушенні структури органу або тканини (рани, вивихи, розтягнення, переломи, тріщини, розриви органів тощо) або функціональних ушкодженнях органів (струс мозку тощо) [9, с. 34]. Варто відзначити, що дослідники розрізняють такі ушкодження:

1. За видом анатомічних структур, тканин, органів і характеру патологічних порушень:

1) ушкодження м'яких тканин: удари, гематоми й крововиливи, рани, розриви сухожиль і м'язів;

2) ушкодження зв'язкового-сумкового апарату суглобів без вивиху в суглобі, з підвивихом або повним вивихом;

3) переломи кісток і переломи-вивихи в суглобах (перелом стегнової кістки і вивих у тазостегновому суглобі);

4) ушкодження внутрішніх органів - черепа, грудей, шлунку й тазу.

2. За ступенем тяжкості розрізняють наступні види ушкоджень:

1) легкі ушкодження - незначні ушкодження, які швидко й безслідно загоюються i не призводять до тимчасової втрати працездатності;
2) середньої тяжкості ушкодження - небезпечні для життя, але вимагають більш тривалого лікування та призводять до тимчасової непрацездатності;

3) тяжкі ушкодження - ушкодження, що створюють загрозу життю, а також які потребують тривалого лікування та призводять до стійкої втрати працездатності;

4) більш тяжкі ушкодження - несумісні 3 життям (вони відразу або найближчим часом призводять до смертельного результату) $[14$, с. 3$]$.

3. У залежності від характеру ушкоджувального фактору ушкодження можуть бути: механічні; термічні; хімічні; психічні [12, с. 33].

Як свідчать результати вивчення слідчої та експертної практики, потерпілому в результаті злочинного посягання заподіюються такі ушкодження м'яких тканин: удари, гематоми, крововиливи, рани, розриви сухожиль і м'язів або пошкодження зв'язкового-сумковою апарату суглобів без вивиху в суглобі або з підвивихи, або повним вивихом, переломи кісток і переломи-вивихи, або пошкодження внутрішніх органів (черепа, грудей, шлунку й тазу). Ці тілесні ушкодження можуть бути виражені в анатомічному порушення структури органу або тканини, або функціональних пошкодженнях.

Викладене свідчить про те, що тілесні ушкодження, завдані потерпілому в результаті злочинного посягання на його життя й здоров'я, виражені в анатомічному порушенні структури його органу або тканини, у функціональних пошкодженнях органів або тканин, є медичними ознаками фізичної шкоди.

У медичній літературі до наслідків шкоди здоров’ю дослідники відносять захворювання. Вони вважають, що захворювання - це порушення життєдіяльність організму при надмірних пошкоджуючих змінах параметрів зовнішнього i внутрішнього середовища, при яких виникає недостатність підтримки гомеостазу за рахунок перенапруження основних і дублюючих механізмів регуляції. Для стану хвороби характерна поява функціональних відхилень від норми, неадекватних відповідей організму 
на подразник, навіть адекватний, розвиток різних порушень на всіх рівнях організації - молекулярно-клітинному, тканинному, органному, системному [15, с. 16]. Як правильно вважає I. Р. Петров, захворювання переважно виявляються в порушенні життєдіяльності організму людини, яке характеризується обмеженою пристосованістю та зниженням працездатності під впливом шкідливих для нього факторів навколишнього середовища [16, с. 289]. Вважаємо, що захворювання може бути наслідком фізичної шкоди, завданої здоров'ю людини.

Більшість учених вважає, що патологічний стан є наслідком ушкодження здоров’я. Патологічний стан - це стійке відхилення від норми, яке має біологічне негативне значення для організму [17, с. 417]. Дещо іншу точку зору має В. В. Михайлов. Він вважає, що патологічний стан - вроджена чи набута після завершення патологічного процесу структурно-функціональна недостатність органів із частковою або повною втратою здатності до відновлення нормальної діяльності (генетичні дефекти обміну речовин, вроджене недорозвинення органів, заміщення втрачених паренхіматозних клітин рубцевою тканиною та ін.) [15, с. 24]. Так, наприклад, працівники міліції м. Черкаси під час допиту Іванова застосовували фізичне насильство та електричний струм, у результаті чого він одержав безліч ушкоджень, які призвели до паталогічного стану, а саме: опіків і посттравматичної невропатії суглобів [18].

Науковий аналіз слідчої та експертної практики свідчить про наявність таких негативних для здоров'я потерпілого наслідків, як інвалідність, тобто міра втрати здоров'я у зв'язку із захворюванням, травмою (ії наслідками) або вродженими вадами, що при взаємодії із зовнішнім середовищем може призводити до обмеження життєдіяльності особи, внаслідок чого держава зобов'язана створити умови для реалізації нею прав нарівні з іншими громадянами та забезпечити iii соціальний захист [19].

У юридичній літературі інвалідність визначається як посвідчення медичним органом стану здоров'я, при якому громадянин, унаслідок хронічного захворювання або ана- томічних дефектів, що викликають стійке, незважаючи на лікування, порушення функцій організму, змушений припинити професійну роботу, може працювати при значних змінах звичайних умов праці [20]. Слушною є думка I. М. Сироти, який вважає, що про інвалідність мова йде тоді, коли розлади функцій організму під впливом хвороби чи внаслідок анатомічного дефекту тягнуть за собою соціальні наслідки - припинення професійної роботи в звичайних умовах чи зміну їі, призначення різних видів соціальної допомоги, встановлення різних пільг і т. ін. [21, с. 155]. У медичній літературі зазначено, що до інвалідності може призвести патологічний стан, захворювання, тілесні ушкодження. Перелік негативних наслідків завданої шкоди здоров'ю, у результаті яких встановлюється група інвалідності, передбачений Інструкцією про встановленні груп інвалідності [22].

\section{Висновки}

На основі аналізу юридичної та медичної літератури можна зробити висновок про те, що наслідком злочинного посягання на потерпілого є заподіяння фізичної шкоди здоров'ю, тобто порушення анатомічної цілісності, фізіологічної функції органів або тканин, що виявляється в тілесному ушкодженні або захворюванні, або патологічному стані, інвалідності.

Вважаємо, що доцільно в Ч.1 ст.3 «Визначення основних термінів Кодексу» КПК доповнити n. 27, в якому визначити поняття бізичної шкоди, спричиненої злочином, як «порушення анатомічної иілісності, фбізіологічно ̈ Функиї органів або тканин, що виявляється в тілесному ушкодженні або захворюванні, або патологічному стані, інвалідності» та ї̈ відикодування потерпілому в повному обсязі.

Пропонуємо доповнити $n .10 \mathrm{~cm} .56$ КПК «Права потерпілого» та викласти їх в наступній редакції: «Потерпілий має право на відшкодування за рахунок держави майнової, фізичної та моральної шкоди, завданої злочином, у тому числі, який не було розкрито органами досудового розслідування, в порядку передбаченому законом.»

Концептуальні положення відповідальності держави перед особою, якій спричи- 
нено фізичну шкоду внаслідок злочинного посягання на життя та здоров'я, потребують належного законодавчого врегулювання в ст.6 Конституції України та Законах України «Про порядок відшкодування шкоди, завданої громадянинові незаконними діями органів, що здійснюють оперативно-розшукову діяльність, органів досудового розслідування, прокуратури і суду», «Про оперативно-розшукову діяльність» та інших.

\section{Аітература}

1. Остапенко С. I. Кримінально-процесуальні гарантії права потерпілого на відшкодування шкоди, завданої злочином: автореф. дис. ... канд. юрид. наук : 12.00.09 Київ, 2010. 19 с.

2. Грищук О. В. Право людини на компенсацію моральної шкоди (загальнотеоретичні аспекти). URL: https://www.academia. edu/3400439/ Право людини на компенсацію моральної шкоди загальнотеоретичні аспекти (дата звернення: 20.12.2019)

3. Зинатуллин 3. 3. Возмещение материального ущерба в уголовном процессе. Казань: Изд-во Казанского ун-та, 1974. 99 с.

4. Әрделевский А. М. Компенсация морального вреда: анализ и комментарий законодательства и судебной практики. - 3-е изд., испр. и доп. М.: Волтерс Клувер, 2004. 320 c.

5. Гаврилов Э. П. Как определить размер компенсации морального вреда? // Российская юстиция. 2000. № 6. с. 28.

6. Васильева О. С. Психология здоровья человека: эталоны, представления, установки : учеб. пособие для студ. высш. учеб. заведений. М.: Академия, 2001. 352 с.

7. Словник термінів, що вживаються в законах України (станом на 1 жовтня 2009 р.) / уклад. В. Д. Андрієнко [та ін.]; Міністерство юстиції України. Центр правової реформи і законопроектних робіт. К. : Фенікс, 2009. 987 с.

8. Большая медицинская энциклопедия: в 30 т./ гл. ред. Б. В. Петровский. 3-е изд. М.: Советская энциклопедия, 1978. T. $8.528 \mathrm{c}$.

9. Новая популярная медицинская энциклопедия / гл. ред. В. И. Покровский. М.:
ООО Издательство «Әнциклопедия», 2004. $768 \mathrm{c.}$

10. Борзенков Г. Н. Квалификация преступлений против жизни и здоровья : учебно-практическое пособие. М.: Зерцало-М, 2005. 144 c.

11. Гурочкин Ю. Д. Судебная медицина : курс лекций. М.: Право и закон, 2003. $320 \mathrm{c}$.

12. Судебная медицина: Общая и особенная части : учебник для вузов / С. Ф. Щадрин, [и др.]. 2-е изд., испр. и доп. М. : Эксмо, 2006. 640 c.

13. Большая медицинская энциклопедия: в 30 т. /гл. ред. Б. В. Петровский. 3-е изд. М.: Советская энциклопедия, 1978. Т. $20.560 \mathrm{c}$.

14. Ключевский В.В. Хирургия повреждений. Ярославль: ДИА-пресс, 1999. 845 с.

15. Михайлов В. В. Основы патологической физиологии : руководство для врачей. М.: Медицина, 2001. 704 с.

16. Безлепкин Б. Т. Отраслевая принадлежность института возмещения ущерба реабилитированным// Советское государство и право. 1989. № 1. С. 65-73.

17. Большая медицинская энциклопедия: в 30 т. /гл. ред. Б. В. Петровский. 3-е изд. М.: Советская энциклопедия, 1978. Т. $18.528 \mathrm{c}$.

18. Копанева Е. Суд освободил из-под стражи жителя Черкасс, которого жестоко пытали в милиции // Факты. URL: http:/ fakty.ua/155697-sud-osvobodil-iz-pod-strazhizhitelya-cherkass-kotorogo-zhestoko-pytali-vmilicii (дата звернення: 12.01.2020)

19. Про реабілітацію осіб з інвалідністю в Україні 06.10.2005 № 2961-IV // База даних «Законодавство України»/Верховна Рада України. URL: https://zakon.rada.gov.ua/laws/ card/2961-15

20. Богословская $\mathcal{\lambda}$. А. Основания к отмене или изменению приговоров. Харьков, 1981. 243 с.

21. Сирота I. М. Право пенсійного забезпечення в Україні: курс лекцій. К.: Юрінком Інтер, 1998. 288 с.

22. Про затвердження Інструкції про встановлення груп інвалідності: Наказ Міністерства охорони здоров'я України від 5 вересня 2011 р. № 561 // База даних «Зако- 


\begin{tabular}{|c|}
\hline 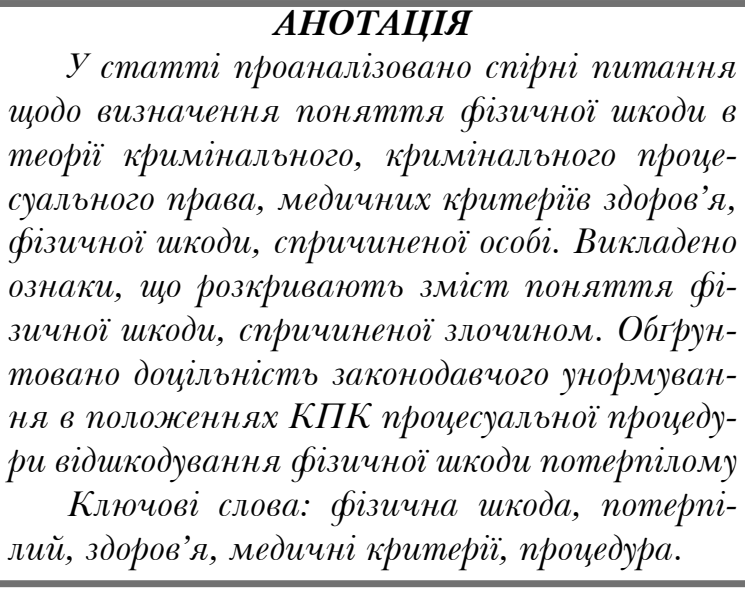 \\
\hline
\end{tabular}

нодавство України»/Верховна Рада України. URL: http://zakon2.rada.gov.ua /laws/show/ z1295-11

Naumova A. $P h D$ in law, associate professor, Department of criminal law and criminology, faculty № 6 , Kharkiv national university of internal affairs (Kharkiv - Ukraine)

PROBLEMS ISSUES OF LEGISLATIVE RESTRICTION OF PHYSICAL DAMAGES.

The purpose of this research is to analyze medical criteria which can be taken as the basis for determining the physical harm caused to a person by criminal acts, and the legal grounds for compensation for the physical harm to the victim in the criminal process.

The methodological basis of the research was the dialectical method of scientific knowledge that made it possible to fully and compre-

\section{SUMMARY}

The article analyzes the controversial issues concerning the definition of the concept of physical harm in the theory of criminal, criminal procedural law, medical criteria of health, physical harm caused to a person. The signs that reveal the meaning of the concept of physical harm caused by a crime are outlined. The expediency of legislative normalization in procedural procedure of compensation procedure for physical harm to the victim is substantiated

Keywords: physical harm, victim, health, medical criteria, procedure.

hensively determine the theoretical and legal problems associated with causing the physical harm to the victim.

The conducted research allows us to make a conclusion that the victim's health is the objective physiological state that he/she had before the criminal infringement. Causing the physical harm, that is disruption of anatomical continuity, physiological function of organs or tissues, that consists in the bodily harm or disease, or pathological state, disability, to the victim is a consequence of the criminal infringe of his/her life and health, and causing the physical harm to the rehabilitated person is a consequence of unlawful actions of bodies of prejudicial inquiry and court.

The medical and legal aspects of the research of the physical harm caused to the victim and the person being rehabilitated are essential for the further development of science, improvement of legislation and practice. 